\title{
Adhesion and inhibition assay of Mycoplasma genitalium and $M$. pneumoniae by immunofluorescence microscopy
}

\author{
HELLE FRIIS SVENSTRUP, PERNILLE K. NIELSEN, METTE DRASBEK*, SVEND BIRKELUND and \\ GUNNA CHRISTIANSEN
}

Department of Medical Microbiology and Immunology, Bartholin Building, University of Aarhus, DK-8000 Aarhus C and *Loke Diagnostics ApS, Science Park, Gustav Wiedsvej 10C, DK-8000 Aarhus C, Denmark

\begin{abstract}
Adhesion of Mycoplasma pneumoniae and the closely related M. genitalium to HEp-2 cells was investigated. The main surface proteins known to be involved in adhesion are $\mathrm{P1}$ of M. pneumoniae and its homologue, MgPa, of M. genitalium. Both proteins are also immunodominant proteins. Protein $\mathrm{P} 116$ is another immunodominant protein of $M$. pneumoniae. These immunogenic proteins were investigated for their surface exposure and involvement in adhesion to host epithelial cells. Immunofluorescence microscopy (IFM) was used to detect $M$. pneumoniae and $M$. genitalium adhering to HEp-2 cells. Monospecific antibodies were produced against fragments of the surface proteins lacking tryptophan stop codons and were used for adhesion detection, surface exposure and adhesion inhibition IFM assays. Three monospecific antibodies were made against MgPa covering regions in the $\mathrm{N}$-terminal, the middle and the $\mathrm{C}$ - terminal part; two monospecific antibodies were produced against $\mathrm{P} 1$ covering regions of the $\mathrm{N}$ - and the C-terminal part and one monospecific antibody was made against most of P116. Only the C-terminal parts of P1 and MgPa were surface exposed and blocking of these regions with the monospecific antibody resulted in inhibition of cytadsorption. Protein P116 was shown to be surface exposed and an essential protein involved in adhesion because the anti-P116 antibody prevented attachment of $M$. pneumoniae to the HEp-2 cells independently of $P 1$. This study adds to the understanding of the molecular biology of $M$. genitalium and $M$. pneumoniae and presents a method to study the proteins involved in adhesion of these mycoplasmas.
\end{abstract}

\section{Introduction}

Mycoplasmas are eubacteria lacking a cell wall. They are the smallest known self-replicating organisms with a cell diameter of only $300 \mathrm{~nm}$ [1] and a genome size in the range of $580 \mathrm{~kb}$ for Mycoplasma genitalium [2] to $1350 \mathrm{~kb}$ for $M$. mycoides [3]. The mycoplasma genome is AT-rich [4] and uses the UGA stop codon to encode tryptophan [5].

M. pneumoniae and the closely related $M$. genitalium are both human pathogens with a specialised tip structure. They use the tip for adhesion to ciliated epithelial host cells, gliding motility [6] and cell division [7,8]. M. pneumoniae is known to colonise ciliated lung epithelia cells and cause an atypical

Received 19 July 2001; accepted 5 Oct. 2001.

Corresponding author: Dr H. F. (Clausen) Svenstrup (e-mail: hellef@biobase.dk). pneumonia. The less well-characterised M. genitalium is believed to be involved in non-gonococcal urethritis [9] and pelvic inflammatory disease [10].

Triton X-100 treatment of whole cells of M. pneumoniae revealed a filamentous, cytoskeleton-like network of proteins (the Triton shell) in the differentiated tip $[11,12]$ analogous to eukaryotic cytoskeleton proteins [13]. The Triton shell proteins are composed primarily of high mol. wt proteins (HMW) $1-3$. These proteins are thought to connect with surface proteins and accessory proteins during adhesion as an energydemanding process [14]. The HMW proteins probably have a scaffolding function that includes the localisation and anchoring of the adhesins to the tip as well as the maintenance of the attachment organelle [15].

Two adhesins have been described to be involved in the attachment of $M$. pneumoniae to host cells: P30 $(32 \mathrm{kDa})$ and the major adhesin P1 (170 kDa). P1 is 
the immunodominant protein but both adhesins elicit immunological responses in man [16-18]. P1 and P30 are clustered specifically in the tip structure of the attachment organelle $[19,20]$ and the adhesins are directly involved in binding to host epithelial receptors [21].

A very immunogenic protein of $116 \mathrm{kDa}(\mathrm{P} 116)$ has also been characterised [22]. Whether this protein is involved in cytadhesion is not known, but the protein is demonstrated to be a surface protein by trypsin degradation [22].

Nearest-neighbour analyses with cross-linking reagents have shown the organisation of the proteins of $M$. pneumoniae associated with the membrane. The analyses revealed that $\mathrm{P} 1$ was located in a complex with adhesin P30, the 40- and $90-\mathrm{kDa}$ surface proteins (ORF-6 cleavage products) and the HMW proteins 1 and 3 in the cell membrane. However, surface protein P116 was not detected as a part of the P1-multiprotein complex [23, 24].

Ultrastructural studies have indicated that M. genitalium is flask-shaped and possesses a cytoskeleton-like structure as seen in M. pneumoniae [25]. Only few proteins involved in cytadhesion have been characterised in M. genitalium. The surface antigen, $\mathrm{MgPa}$ $(150 \mathrm{kDa})$, is the major adhesin of M. genitalium and it is homologous to the major $\mathrm{P} 1$ adhesin of $M$. pneumoniae (51.7\% amino acid (aa) identity) [26]. Furthermore, $\mathrm{MgPa}$ is the most immunogenic protein of M. genitalium [27-29]. Recently, two putative cytadherence-related proteins of $M$. genitalium, P32 and P69, have been described but the functional activities of these proteins are still unproven [30]. The hypothetical protein, MG075, of M. genitalium is homologous to P116 of M. pneumoniae $(52.2 \%$ aa identity) [2] but expression of MG075 has not been demonstrated [31]. A second immunodominant protein, P114, was identified as being encoded by MG192 (114$\mathrm{kDa}$ protein of the $\mathrm{MgPa}$-operon) and not related to P116 [29, 32].

Recombinant proteins covering specific domains of $\mathrm{MgPa}$ of M. genitalium as well as of P1 and P116 of M. pneumoniae were produced to study attachmentmediating regions. Polyclonal monospecific antibodies were produced by immunising rabbits with the recombinant proteins. Indirect immunofluorescence microscopy (IFM) was used to investigate whether these monospecific antibodies were able to inhibit the cytadsorption of $M$. genitalium and M. pneumoniae.

\section{Materials and methods}

\section{Micro-organisms}

M. genitalium G37 and M. pneumoniae FH (ATCC, MD, USA) were cultured in $100 \mathrm{ml}$ of SP-4 medium
[33] in TTP tissue-culture flasks (Medi Cult, Copenhagen, Denmark) and incubated at $37^{\circ} \mathrm{C}$. After growth for $48 \mathrm{~h}$, the medium changed colour from red to orange which indicated an exponential growth phase and the cells were harvested. Mycoplasma cells attached to the bottom of the culture flask were scraped off in phosphate-buffered saline $(0.01 \mathrm{M}$ sodium phosphate, $\mathrm{NaCl} 0.85 \%, \mathrm{pH} 7.4$; PBS) and the cells were pelleted by centrifugation at $10000 \mathrm{~g}$ for $30 \mathrm{~min}$. The cells were resuspended in $4 \mathrm{ml}$ of PBS and centrifuged in eppendorf tubes at $20000 \mathrm{~g}$ for $15 \mathrm{~min}$. The supernate was removed and the pellets were stored at $-70^{\circ} \mathrm{C}$ [29].

\section{Extraction of mycoplasma DNA}

One pellet of M. genitalium and M. pneumoniae from cultivation in $20 \mathrm{ml}$ of SP-4 medium [33] (5 pellets/ $100 \mathrm{ml}$ ) was individually dissolved in $160 \mathrm{ml}$ of TrisEDTA buffer [34] with $40 \mu \mathrm{l}$ of proteinase $\mathrm{K}$ (Boehringer Mannheim GmbH, Germany) $200 \mu \mathrm{g} / \mathrm{ml}$. The solution was incubated at $37^{\circ} \mathrm{C}$ for $30 \mathrm{~min}$ after incubation at $55^{\circ} \mathrm{C}$ for $30 \mathrm{~min}$ and then boiled for $5 \mathrm{~min}$. The extracted DNA was stored at $-20^{\circ} \mathrm{C}$.

\section{Generation of recombinant proteins}

Expand $^{\text {TM }}$ High Fidelity PCR System (Boehringer Mannheim) was used to amplify the genes encoding the M. genitalium protein, $\mathrm{MgPa}$, and the M. pneumoniae proteins, $\mathrm{P} 1$ and $\mathrm{P} 116$. Primers to amplify the $m g p a, p 1$ and $p 116$ genes were designed from the nucleotide sequences with GenBank accession nos M31431 (strain G37), M18639 (strain M129) and Z71425 (strain M129). Nested PCR was done with the mgpa and pl gene because of homologous repetitive sequences scattered in the genomes of $M$. genitalium and $M$. pneumoniae, respectively (the nested primers are shown in Table 1). The positions of the primers for the production of recombinant proteins were limited by tryptophan stop codons. Three fragments of mgpa were amplified covering nucleotides (nt) 229-960 (no. I), nt 2488-3027 (no. II) and nt 3223-4332 (no. III). Two fragments of $p 1$ were amplified covering nt 553-1056 (no. I) and nt 3295-4530 (no. II). The major part of p116 was amplified covering nt $1-2883$. The primers that were used to generate recombinant proteins were designed with histidine-tags: forward primer, 5'-GAC GACGACAAGATX-insert specific sequence-3'; reverse primer, 5'-GAGGAGAAGCCCGGT-insert specific sequence- $3^{\prime}$. All the primers were purchased from DNA Technology APS, Aarhus, Denmark, and are shown in Table 1.

High Fidelity PCR was performed as described previously [29]. The PCR products were annealed to the pET-30 Ek/LIC vector with the Ligation Independent Cloning (LIC) kit (Novagen, Madison, USA) as prescribed by the manufacturer. The recombinant plasmids were expressed in Escherichia coli NovaBlue Singles Competent Cells and subsequently purified by 
Table 1. List of primers used to amplify DNA fragments for the production of recombinant proteins

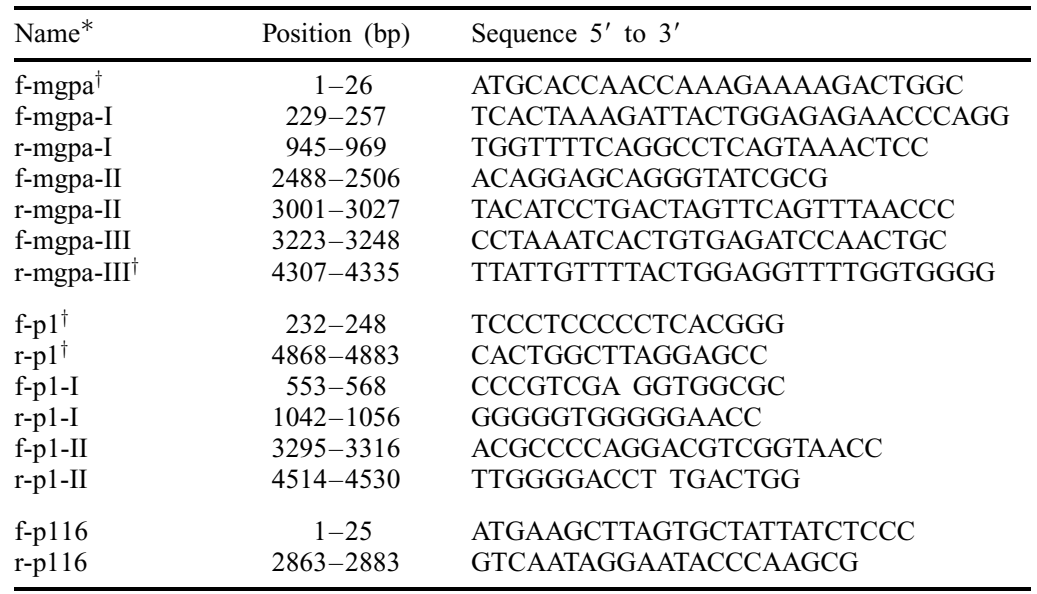

All primers were purchased from DNA technology ApS, Aarhus, Denmark.

* The first letter of the primer name denotes the direction of the primer: $f$, forward;

$\mathrm{r}$, reverse.

$\dagger$ Primers used for nested PCR.

alkaline lysis as described by Sambrook et al. [34]. The purified plasmid vectors were transformed into E. coli BL21(DE3) competent cells. For expression of recombinant proteins, E. coli BL21(DE3) were induced with $0.5 \mathrm{mM}$ iso-propyl-thio-galactoside (IPTG) for $2.5 \mathrm{~h}$ at $37^{\circ} \mathrm{C}$ [34]. The recombinant proteins were purified with HiTrap $^{\mathrm{TM}}$ affinity columns (Amersham Pharmacia Biotech) according to the manufacturer's instructions. The recombinant proteins were denoted $\mathrm{rMgPa}-\mathrm{I}$,
rMgPa-II, rMgPa-III, rP1-I, rP1-II and rP116 and are schematically outlined in Fig. 1.

\section{Production of rabbit polyclonal antibodies (Pabs)}

Rabbit Pabs were produced as described previously [35]. $\mathrm{Pab}$ was produced against whole cells of $M$. genitalium G37 (denoted PabG37). Pab against whole cells of $M$. pneumoniae FH (denoted PabFH) was purchased from

a $\operatorname{MgPa}(1444 \mathrm{aa})$ :

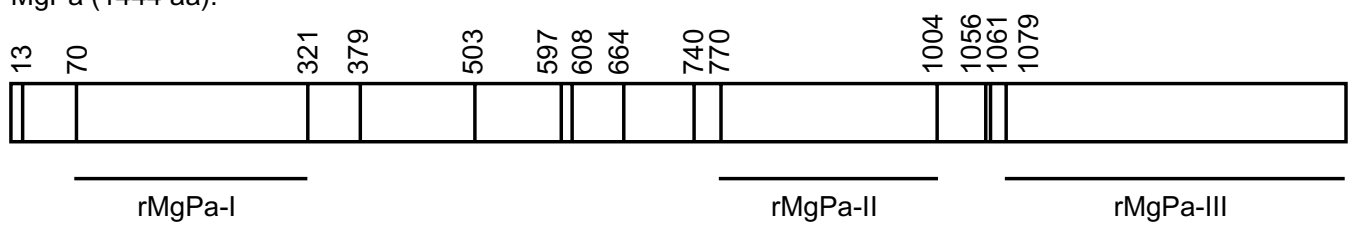

b P1 (1627 aa):

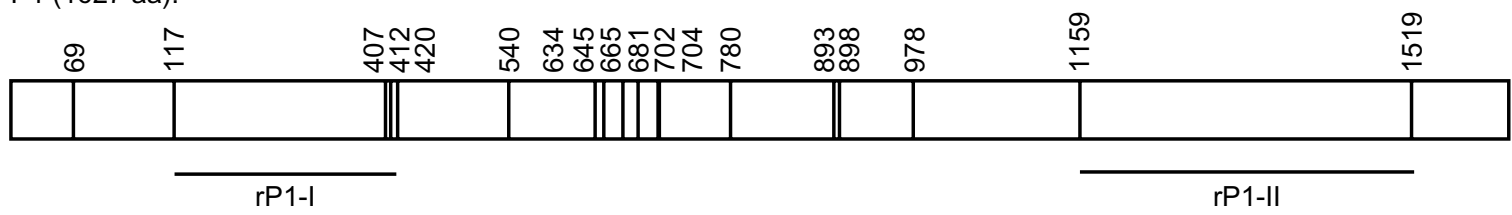

c P116 (1030 aa):

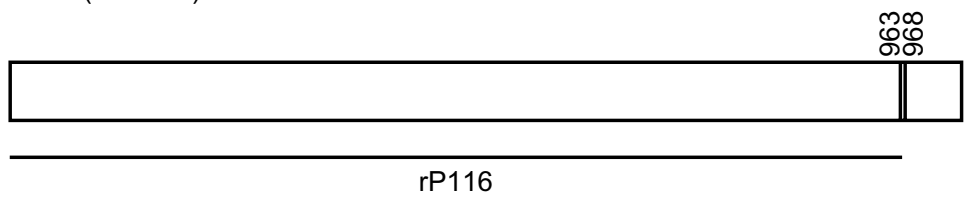

Fig. 1. Schematic illustration of (a) MgPa, (b) P1 and (c) P116 amino acid (aa) sequences showing the position of tryptophan encoded by the UGA stop-codon (black vertical lines). The locations of the recombinant proteins used for the production of monospecific antibodies are shown below each aa sequence (black horizontal lines). 
the WHO Mycoplasma Reference Center, Aarhus University, Denmark. Rabbit monospecific antibodies were produced against recombinant proteins as described previously [29]. The sera were denoted $\mathrm{Pab}()$ with the name of the recombinant protein in brackets: Pab(rMgPa-I), Pab(rMgPa-II), Pab(rMgPa-III), Pab(rP1I), Pab(rP1-II) and Pab(rP116).

\section{SDS-PAGE and immunoblotting}

Protein $(100 \mu \mathrm{g})$ of $M$. genitalium or M. pneumoniae whole cells or recombinant proteins $(50 \mu \mathrm{g})$ were dissolved in $150 \mu \mathrm{g}$ of SDS sample buffer $(62.5 \mathrm{mM}$ Tris-HCl, pH 6.8, glycerol $10 \% \mathrm{v} / \mathrm{v}$, SDS $2.3 \% \mathrm{w} / \mathrm{v}, \beta$ mercaptoethanol $5 \% \mathrm{v} / \mathrm{v}$, bromphenol blue $0.05 \% \mathrm{w} / \mathrm{v}$ ) and boiled for $2 \mathrm{~min}$. The proteins were separated by SDS-PAGE in $7.5 \%$ or SDS-polyacrylamide $10 \%$ gels containing a $5 \%$ stacking gel.

The proteins were transferred to nitrocellulose (Schleicher \& Schull, Dassel, Germany) by electroblotting. The marker was cut from the membrane and stained with Amido Schwartz for $2 \mathrm{~min}$. The rest of the membrane was blocked with blocking buffer $(20 \mathrm{mM}$ Tris-base, $500 \mathrm{mM} \mathrm{NaCl}$, gelatine $3 \%$ ) for $15 \mathrm{~min}$ at $37^{\circ} \mathrm{C}$.

The immunostaining was performed by a method of BioRad. The membrane was cut into 3-mm strips and incubated with primary antibodies for $1 \mathrm{~h}$ at $37^{\circ} \mathrm{C}$. The rabbit sera were diluted 1 in 1000 in antibody buffer (20 mM Tris-base, $500 \mathrm{mM} \mathrm{NaCl}$, gelatine 3\%, Tween$200.05 \%$ ). The secondary antibody used was alkaline phosphatase (AP)-conjugated goat anti-rabbit IgG $(\mathrm{H}+\mathrm{L})$ diluted 1 in 3000 and incubated with strips for another hour. The membrane was washed with washing buffer $(20 \mathrm{~mm}$ Tris-base, $500 \mathrm{mM} \mathrm{NaCl}$, Tween-20 $0.05 \%$ ) after each incubation. Finally, the strips were developed for $10 \mathrm{~min}$ with nitroblue tetrazolium and 5-bromo-4-chloro-3-indolyl phosphate p-toludium (NBT/BCIP) solution.

\section{Preparation of HEp-2 cells for infection with mycoplasma}

The human cell line, HEp-2 (ATCC, MD, USA), was cultured in TTP tissue-culture flasks (Medi Cult, Copenhagen, Denmark) containing RPMI-1640 medium (Gibco BRL, Grand Island, NY, USA) with $25 \mathrm{~mm}$ Hepes-buffer $(0.01 \mathrm{M}$ N-2-hydroxyethylpiperazine-N' 2-ethanesulphonic acid, $0.15 \mathrm{M} \mathrm{NaCl}, \mathrm{pH} 7.2$ ), sodium bicarbonate, fetal calf serum $10 \%$, gentamicin $\mathrm{mg} / \mathrm{L}$ and $2 \mathrm{~mm}$ glutamine, $\mathrm{pH} 7.2$.

The HEp-2 cells were transferred to 24-well Multi-dish plates (Nunc, Roskilde, Denmark) with sterile glass coverslips by loosening the cells with PBS containing trypsin $0.25 \%$ and EDTA $0.02 \%$. The cell concentration was adjusted to $50000 \mathrm{HEp}-2$ cells $/ \mathrm{ml}$ of 1640 RPMI medium with penicillin $(100 \mathrm{U} / \mathrm{ml}) 0.05 \%$ and
$1 \mathrm{ml}$ of the cell suspension was added per well. The plates were incubated overnight in air with $\mathrm{CO}_{2} 5 \%$ at $37^{\circ} \mathrm{C}$.

\section{Preparation of mycoplasma for infection of HEp- 2 cells}

M. genitalium and M. pneumoniae were cultured in 10$\mathrm{ml}$ tissue-culture flasks as described previously [29]. The mycoplasmas were scraped off in $10-12 \mathrm{ml}$ of RPMI with penicillin $(100 \mathrm{U} / \mathrm{ml}) \quad 0.05 \%$ ready for infection of the HEp-2 cells. To avoid the noticeable self-aggregating feature of $M$. pneumoniae, the suspension was sheared through a $27 \mathrm{G}$ needle.

\section{Adhesion detection assay}

HEp-2 cells, in RPMI with penicillin (750 $\mu \mathrm{l} /$ well), were infected with the mycoplasma RPMI-suspension (50 $\mu \mathrm{l} /$ well) and incubated for $2 \mathrm{~h}$. The infected HEp-2 cells were fixed in methanol $100 \%$ at $4{ }^{\circ} \mathrm{C}(0.5 \mathrm{ml} /$ well $)$ for $1 \mathrm{~min}$ and washed with PBS. To detect the adhering mycoplasmas, primary Pabs were added for $30 \mathrm{~min}$ at $37^{\circ} \mathrm{C}$ (PabG37 and PabFH were diluted 1 in 2000 and 1 in 1000 respectively, the monospecific antibodies were diluted 1 in 500). A solution $(300 \mu \mathrm{l})$ of secondary fluorescein isothiocyanate (FITC)-conjugated 'Affinipure' goat anti-rabbit (GaR) IgG $(\mathrm{H}+\mathrm{L})$ (Jackson Immuno Research Laboratories, Pennsylvania, USA) diluted 1 in 100 (FITC-conjugated GaR $\mathrm{IgG}$ ) and Evans Blue diluted 1 in 10 was added to each well for $30 \mathrm{~min}$ at $37^{\circ} \mathrm{C}$. The cells were washed twice in PBS before and after the addition of antibodies.

\section{Surface exposure assay}

To detect surface proteins of the mycoplasmas, the primary antibodies were added before methanol fixation. Otherwise, the procedure was the same as described for the adhesion detection assay.

\section{Adhesion inhibition assay}

The mycoplasma suspension $(50 \mu \mathrm{l})$ was pre-incubated for $30 \mathrm{~min}$ at $37^{\circ} \mathrm{C}$ with $50 \mu \mathrm{l}$ of different antibody solutions ( 1 in 50, 1 in 100,1 in 200 and 1 in 400) before incubation of the HEp-2 cells. The mycoplasmaantibody suspension $(100 \mu \mathrm{l})$ was then added to the HEp-2 cells together with $700 \mu 1$ of RPMI with penicillin and incubated overnight in air with $\mathrm{CO}_{2}$ $5 \%$ at $37^{\circ} \mathrm{C}$. Fixation and addition of secondary antibodies were as described in the adhesion detection assay.

\section{Indirect immunofluorescence microscopy (IFM)}

Samples prepared for the adhesion detection, surface exposure and inhibition assays were investigated by IFM. A drop of anti-fade solution (p-phenyldiamine dihydrochloride $1 \mu \mathrm{g} / \mathrm{ml}$ in PBS $10 \%$ and glycerol 
$90 \%, \mathrm{pH} 9.0$ ) was placed between the glass coverslips and the slides. Fluorescence microscopy was performed with a Leitz DMR fluorescence microscope (Leica Mikroskopie and Systeme GmbH, Wetzlar, Germany).

\section{Results}

\section{Recombinant proteins}

Recombinant proteins were produced to investigate the adhesion domains of $\mathrm{MgPa}$ of $M$. genitalium and $\mathrm{P} 1$ and $\mathrm{P} 116$ of $M$. pneumoniae. Because the UGA tryptophan codon will create a stop codon in E. coli, the regions cloned were limited. Three regions of $\mathrm{MgPa}$ were cloned located in the N-terminal, the middle and the C-terminal part (denoted rMgPa nos I-III; Fig. 1a). Two regions of $\mathrm{P} 1$ covering the $\mathrm{N}$ - and the $\mathrm{C}$-terminal part were cloned (denoted rP1 nos I-II; Fig. 1b). Almost the entire P116 was produced as one recombinant protein because the only two tryptophan UGA codons present are located in the C-terminal part (denoted rP116; Fig. 1c).

\section{SDS-PAGE and immunoblotting of recombinant proteins}

The purified recombinant proteins were separated by gel electrophoresis and stained with Coomassie Brilliant Blue $(\mathrm{CBB})$ or transferred to nitrocellulose for immunoblotting. SDS-PAGE of $\mathrm{rMgPa}$ (nos I-III) is shown in Fig. 2a (lanes denoted CBB). In immunoblotting with $\mathrm{rMgPa}$ (nos I-III) (Fig. 2a, lanes denoted IMB) polyclonal antibody against whole cells of $M$. genitalium, $\mathrm{Pab}(\mathrm{G} 37)$, did not react with $\mathrm{rMgPa}-\mathrm{I}$, but reacted moderately with rMgPa-II and strongly with rMgPa-III.

SDS-PAGE of rP1 (nos I-II) and rP116 is shown in Fig. 2b (lanes CBB). In immunoblotting with rP1 (nos I and II) and rP116 (Fig. 2b, lanes IMB) polyclonal antibody against whole cells of $M$. pneumoniae, $\mathrm{Pab}$ $(\mathrm{FH})$, did not react with $\mathrm{rP} 1$ but reacted strongly with rP1-II and rP116.

\section{Monospecific Pab}

Rabbits were immunised with the purified recombinant proteins for the production of monospecific antibodies. In immunoblotting with whole-cell proteins of $M$. genitalium $\mathrm{Pab}(\mathrm{rMgPa})$ nos $\mathrm{I}-\mathrm{III}$ and all the monospecific antibodies reacted strongly with $\mathrm{MgPa}$ (Fig. 2c). Correspondingly, in immunoblotting with wholecell proteins of $M$. pneumoniae $\mathrm{Pab}(\mathrm{rP} 1)$ nos I and II and $\mathrm{Pab}(\mathrm{rP} 116)$, the Pabs reacted strongly with $\mathrm{P} 1$ and P116, respectively (Fig. 2d).

\section{Indirect immunofluorescence microscopy (IFM)}

IFM was performed to analyse (i) the suitability of the monospecific antibodies for detecting the mycoplasmas adhering to the HEp-2 cells (adhesion detection assay), (ii) the reaction of the monospecific antibodies with the surface of the mycoplasmas (surface exposure assay) and (iii) the ability of the monospecific antibodies to inhibit cytadsorption (adhesion inhibition assay). HEp2 cells, derived from a laryngeal carcinoma, were used as host epithelial cells in the adhesion and the inhibition assays.

\section{Adhesion detection assay}

HEp-2 cells, infected either with $M$. genitalium or $M$. pneumoniae, were methanol-fixed before exposing them to the primary antibodies. Methanol is a strong fixative that denatures most proteins and removes lipids in the cell membrane, thus allowing antibodies to penetrate the mycoplasma cells. The bound primary antibodies were detected with an FITC-conjugated goat anti-rabbit immunoglobulin ( $\operatorname{IgG})$.

Monospecific Pab(rMgPa) nos I-III were all able to identify $M$. genitalium microcolonies attached to the HEp-2 cells, as visualised by the green fluorescence spots scattered all over the surface of the HEp-2 cells (Fig. 3a-c). However, Pab(rMgPa-II) did not react as strongly as the other two monospecific antibodies (Fig. 3b). Polyclonal antibody against whole cells of $M$. genitalium, Pab(G37), strongly detected cytadhering mycoplasmas on the HEp-2 cells and served as a positive control (Fig. 3d).

The monospecific antibodies $\mathrm{Pab}(\mathrm{rP} 1)$ nos I and II and $\mathrm{Pab}(\mathrm{rP} 116)$ were all able to identify $M$. pneumoniae cells bound to the HEp-2 cells (Fig. 3e-g). Large green fluorescent spots were identified, showing that the cells of M. pneumoniae were clustered on the HEp-2 cells. A polyclonal antibody against whole cells of $M$. pneumoniae, $\mathrm{Pab}(\mathrm{FH})$, strongly detected the cytadsorbed cells of M. pneumoniae and served as a positive control (Fig. 3h). In general, the cells of M. pneumoniae tended to form micro-colonies rather than adhering as single cells. M. genitalium also produced minute colonies but they were smaller than the colonies of M. pneumoniae.

\section{Surface exposure assay}

To detect the accessibility of the antibodies on the surface of the cytadhering mycoplasmas, the primary detecting antibodies were added before fixation with methanol. Again, the bound primary antibodies were visualised by FITC-conjugated IgG.

The monospecific $\mathrm{Pab}(\mathrm{rMgPa}-\mathrm{I})$ and $\mathrm{Pab}(\mathrm{rMgPa}-\mathrm{II})$ were not able to detect the attached M. genitalium cells on the HEp-2 cells (Fig. $3 \mathrm{i}$ and j), whereas both $\mathrm{Pab}(\mathrm{rMgPa}-\mathrm{III})$ and $\mathrm{Pab}(\mathrm{G} 37)$ (Fig. 3k and 1) revealed cytadhering mycoplasmas visualised as green fluorescence spots dispersed on the HEp-2 cells. Likewise, no fluorescence was observed when the monospecific Pab(P1-I) was 
a

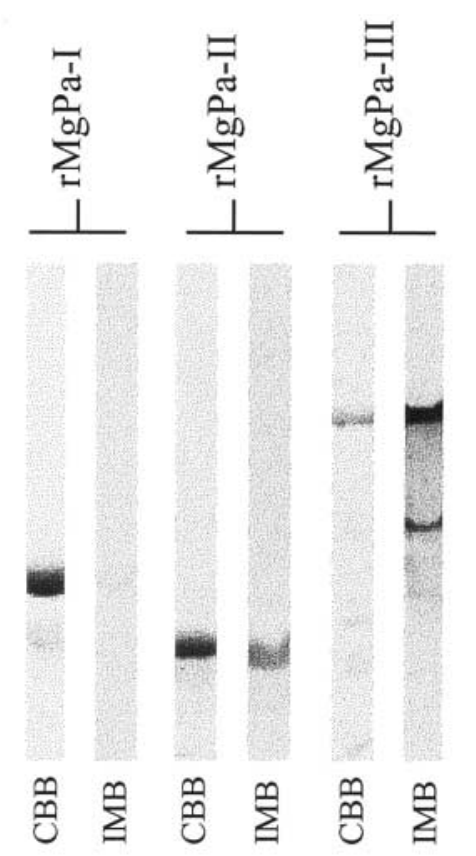

c

M. genitalium

b

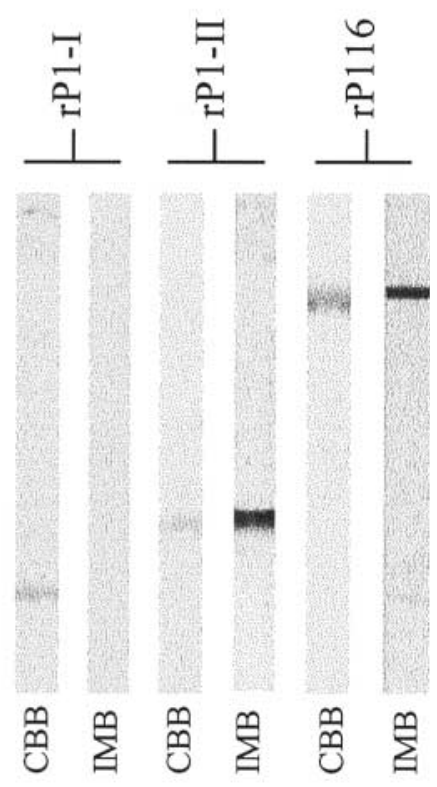

d

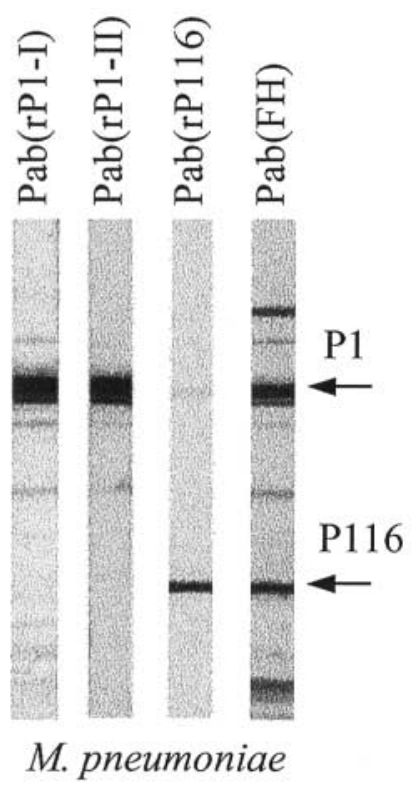

Fig. 2. SDS-PAGE of (a) recombinant MgPa of M. genitalium stained with Coomassie Brilliant Blue (lane CCB) and reacted with $\mathrm{Pab}(\mathrm{G} 37)$ in immunoblotting (lane IMB). Note that $\mathrm{Pab}(\mathrm{G} 37)$ did not react with $\mathrm{rMgPa}-\mathrm{I}$, reacted intermediately with $\mathrm{rMgPa}-\mathrm{II}$ and strongly with rMgPa-III. (The faster running protein band (lane rMgPa-III, IMB) is a degradation product of rMgPa-III.) (b) Recombinant proteins, P1 and P116 of M. pneumoniae stained with CCB and Pab(FH) in IMB. Note that Pab(FH) did not react with P1-I and reacted strongly with P1-II and P116. Immunoblotting of whole cells of (c) M. genitalium reacted with monospecific antibodies directed against N-terminal, middle and C-terminal part of $\mathrm{MgPa}$. All antibodies reacted intensely with $\mathrm{MgPa}$. Pab(G37) directed against whole cells of M. genitalium served as a control. (d) M. pneumoniae reacted with monospecific antibodies directed against the $\mathrm{N}$ - and $\mathrm{C}$-terminal part of $\mathrm{P} 1$ and P116. All antibodies reacted strongly with $\mathrm{P} 1$ and $\mathrm{P} 116$, respectively. Pab(FH) directed against whole cells of M. pneumoniae is included as a control.

added to the HEp-2 cells infected with $M$. pneumoniae (Fig. 3m), whereas Pab(P1-II), Pab(P116) and Pab(FH) were all able to detect $M$. pneumoniae cells attached to the HEp-2 cells (Fig. $3 n-$ p).

Negative controls included in the adhesion detection and surface exposure assay were cells of $M$. genitalium and M. pneumoniae adhering to HEp-2 cells without antibodies (Fig. 3q, Table 2) and antibodies without mycoplasmas (Fig. 3r, Table 2) to ensure that nonspecific binding of the antibodies did not occur.

\section{Adhesion inhibition assay}

The adhesion inhibition assay examined whether the monospecific antibodies were able to block either $M$. 

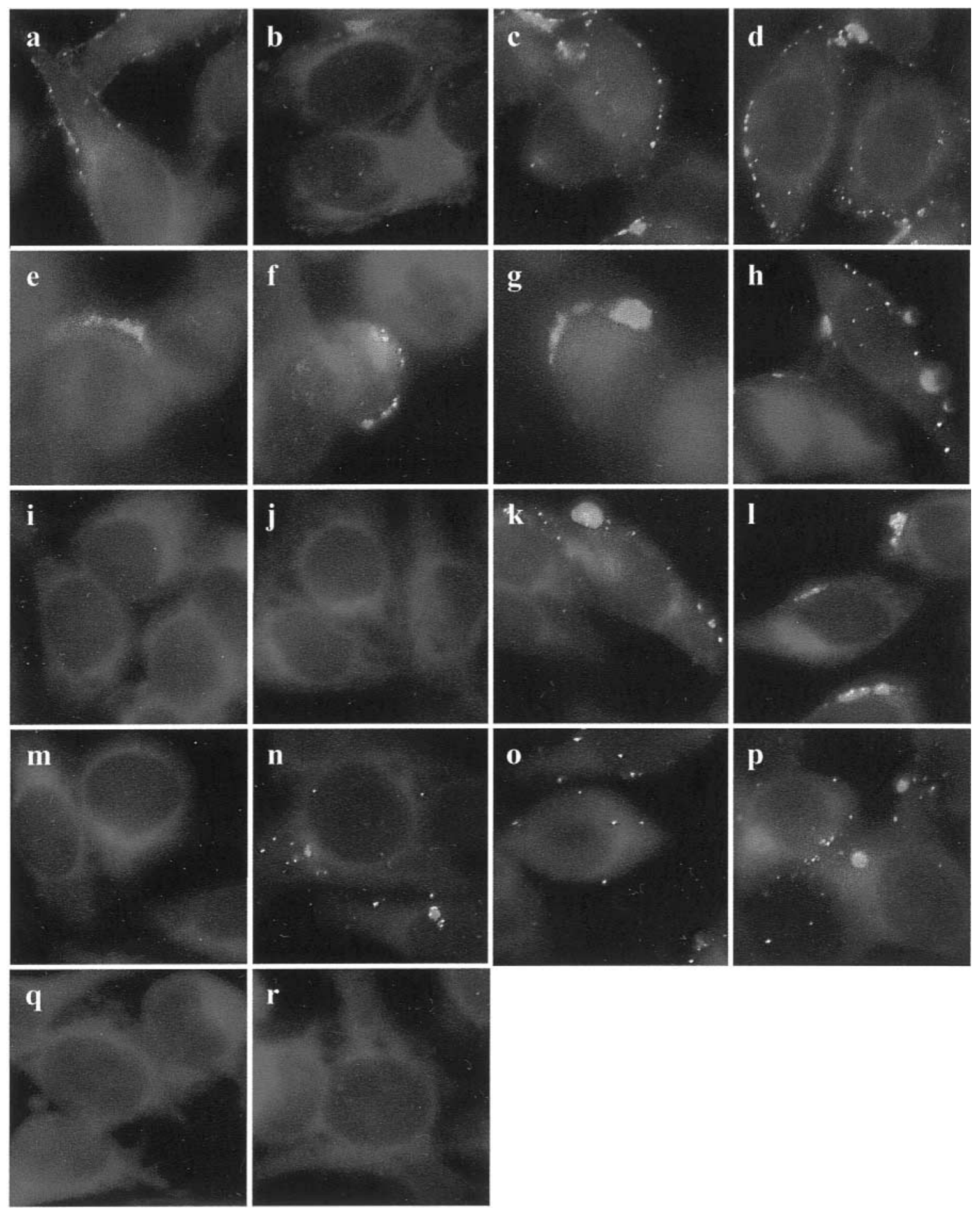

Fig. 3. IFM adhesion detection assay of $M$. genitalium $(\mathrm{a}-\mathrm{d})$ and $M$. pneumoniae $(\mathrm{e}-\mathrm{h})$. The mycoplasmas attached to the HEp-2 cells were detected by either polyspecific or monospecific antibodies. The detecting antibodies were added after fixation with methanol: (a) Pab(rMgPa-I), (b) Pab(rMgPa-II), (c) Pab(rMgPa-III), (d) Pab(G37), (e) Pab(rP1-I), (f) Pab(rP1-II), (g) Pab(rP116) and (h) Pab(FH). IFM surface exposure assay of M. genitalium (i-1) and M. pneumoniae (m-p). (i) Pab(rMgPa-I). In this assay the detecting antibodies were added before the methanol fixation: (j) Pab(rMgPa-II), (k) Pab(rMgPa-III), (l) Pab(G37), (m) Pab(rP1-I), (n) Pab(rP1-II), (o) Pab(rP116) and (p) Pab(FH). The negative controls were: (q) mycoplasmas alone (no Pabs) and (r) Pabs alone (no mycoplasmas). Bar, $10 \mu \mathrm{m}$.

genitalium or $M$. pneumoniae from binding to the HEp-2 cells. Dilution series ( 1 in 50, 1 in 100,1 in 200 or 1 in 400) of monospecific antibodies were incubated with the mycoplasmas before infection of the HEp-2 cells to test their adherence inhibitory effect. The cytadhering mycoplasmas were detected with polyclo- nal antibodies against whole cells of $M$. genitalium, $\mathrm{Pab}(\mathrm{G} 37)$, and $M$. pneumoniae, $\mathrm{Pab}(\mathrm{FH})$, rather than the weaker binding monospecific antibodies (see the adhesion detection assay). Again, the mycoplasmas attached to the HEp-2 cells were visualised by the secondary FITC-conjugated goat-anti rabbit IgG. 
Table 2. Adhesion of M. genitalium and M. pneumoniae to HEp-2 cells measured by IFM

\begin{tabular}{lcc}
\hline Pab & $\begin{array}{c}\text { Adhesion } \\
\text { detection assay }\end{array}$ & $\begin{array}{c}\text { Surface } \\
\text { exposure assay }\end{array}$ \\
\hline M. genitalium & + & - \\
rMgPa-I & + & - \\
rMgPa-II & + & + \\
rMgPa-III & + & + \\
G37 & & - \\
M. pneumoniae & + & + \\
rP1-I & + & + \\
rP1-II & + & + \\
rP116 & + & - \\
FH & & - \\
Negative controls & - & \\
Pab (no mycoplasma) & - & \\
Mycoplasma (no Pab) & - & \\
\hline
\end{tabular}

*Pabs include: Pab(rMgPa-I), Pab(rMgPa-II), Pab(rMgPa-III), Pab(rP1-I), Pab(rP1-II) and Pab(rP116).

The polyspecific antibodies, $\mathrm{Pab}(\mathrm{G} 37)$ and $\mathrm{Pab}(\mathrm{FH})$, were included in the adhesion inhibition assay as inhibiting antibodies because they were expected to reduce the numbers of cytadhering $M$. genitalium and M. pneumoniae. Addition of $\mathrm{Pab}(\mathrm{G} 37)$ (Fig. $4 \mathrm{a}-\mathrm{d}$ and Fig. 5a4) and $\mathrm{Pab}(\mathrm{FH})$ (Fig. $4 \mathrm{e}-\mathrm{h}$ and Fig. 5b5) also showed that mycoplasmas were inhibited from binding to the HEp-2 cells by increasing the antibody concentration. This correlation decreased nearly exponentially with almost no inhibition with the minimum antibody concentration (1 in 400) and only 5\% of M. genitalium and $9 \%$ of $M$. pneumoniae adhering to the HEp-2 cells at the maximal concentration of antibody (1 in 50) compared with positive controls (Fig. 4a-h, Table 3). Mycoplasma-infected HEp-2 cells without antibody and with pre-immune serum served as positive controls (Fig. 4y, Table 3) (adhesion detection assay).

Similarly, the adhesion inhibition assay was performed with monospecific antibodies against different parts of $\mathrm{MgPa}$ of M. genitalium (Pab(rMgPa) nos I-III). No inhibition of cytadsorption of $M$. genitalium was observed with either Pab(rMgPa-I) or Pab(rMgPa-II) because numerous cells of $M$. genitalium $(86 \%$ and $61 \%$, respectively) were seen on the HEp-2 cells when the 1 in 50 dilution was used (Fig. $4 \mathrm{u}$ and v, Fig. 5a1 and 2). In contrast, Pab(rMgPa-III) was shown to inhibit the binding of M. genitalium to the HEp-2 cells as seen in Fig. 4i-1, showing the dilution series. $\mathrm{Pab}(\mathrm{rMgPa}-\mathrm{III})$ inhibited the cytadsorption of $M$. genitalium just as well as the polyspecific $\mathrm{Pab}(\mathrm{G} 37)$ as seen in the exponential decreasing plots (Fig. 5a3 and 4). The cytadherence of $M$. genitalium was reduced to $c$. $3 \%$, when $\mathrm{Pab}(\mathrm{rMgPa}-\mathrm{III})$ was diluted 1 in 50 (Table 3).

No inhibition of adhesion of M. pneumoniae to HEp-2 cells was observed with $\mathrm{Pab}(\mathrm{rP} 1-\mathrm{I})$ (Fig. $4 \mathrm{x}$ ), as no decrease in the number of attached cells of $M$. pneumoniae was observed when the antibody concen- tration was increased. When the maximal antibody concentration was used for inhibition, 94\% of the micro-colonies were still attached to the HEp-2 cells (Fig. 5b1 and Table 3). In contrast, Pab(rP1-II) and Pab(rP116) both inhibited the adsorption of $M$. pneumoniae to the HEp-2 cells as seen in Fig. $4 \mathrm{~m}-\mathrm{p}$ and Fig. $4 \mathrm{q}-\mathrm{t}$ showing the dilution series. Pab(rP116) inhibited $M$. pneumoniae to the same extent as Pab(rP1-II) (Fig. 5b2 and 3) but, when the antibodies were added together, it seemed that the inhibitory effect of these was increased. The plot of inhibition caused by a mixture of $\mathrm{Pab}(\mathrm{rP} 1-\mathrm{II})$ and $\mathrm{Pab}(\mathrm{rP} 116)$ is shown in Fig. $5 \mathrm{~b} 4$ and appeared very similar to the plot of $\mathrm{Pab}(\mathrm{FH})$ (Fig. 5b5). The average number of attached $M$. pneumoniae micro-colonies at the maximal antibody dilution ( 1 in 50) of mixed anti-P1 and anti-P116 was reduced to $6 \%$ of that of the positive controls (Table 3). The reduction of attached M. pneumoniae was slightly lower when Pab(rP1-II) and Pab(rP116) were used alone, with the higher percentages of $15 \%$ and $10 \%$ (Fig. $5 \mathrm{~b} 2$ and 3, Table 3).

\section{Discussion}

This study shows evidence for the surface exposure of $\mathrm{MgPa}$ of $M$. genitalium and $\mathrm{P} 1$ and $\mathrm{P} 116$ of $M$. pneumoniae as well as the involvement of the proteins in adhesion to host epithelial cells. The surface exposure of $\mathrm{MgPa}, \mathrm{P} 1$ and P116 has been determined in several studies with trypsination $[22,27,36]$. Failure of adherence to tracheal explants after protease treatment following re-attachment when P1 was regenerated demonstrated $\mathrm{P} 1$ as an attachment factor. The $\mathrm{P} 1$ protein is considered to be the major ligand mediating attachment of virulent M. pneumoniae to the host cell membrane and clustering of $\mathrm{P} 1$ at the tip-organelle is decisive for a successful adhesion [19]. An earlier study showed that pre-treatment of $M$. pneumoniae with antiserum directed against P1 blocked cytadherence to hamster tracheal rings by up to $80 \%$ [37]. Electron microscopy with monoclonal antibodies (MAbs) produced against $\mathrm{MgPa}$ of $M$. genitalium revealed that the protein is located mainly in the tip structure, which suggested $\mathrm{MgPa}$ to be the counterpart of P1 [27].

It was shown by IFM that, of the protein regions investigated in this study, only the C-terminal part of $\mathrm{MgPa}$ (aa 1075-1444) and the C-terminal part of P1 (aa 1107-1518) are exposed on the surface of $M$. genitalium and $M$. pneumoniae. These results were consistent with the adhesion inhibition experiments showing that blocking of the C-terminal part of $\mathrm{MgPa}$ of $M$. genitalium and the C-terminal part of P1 of $M$. pneumoniae by monospecific antibodies inhibited the mycoplasmas from binding to HEp-2 cells. This indicates that the C-terminal part of both $\mathrm{MgPa}$ and P1 is involved in cytadhesion. However, the possibility that steric hindrance by the monospecific antibody bound to the $\mathrm{C}$-terminal part might cause the inhibition 


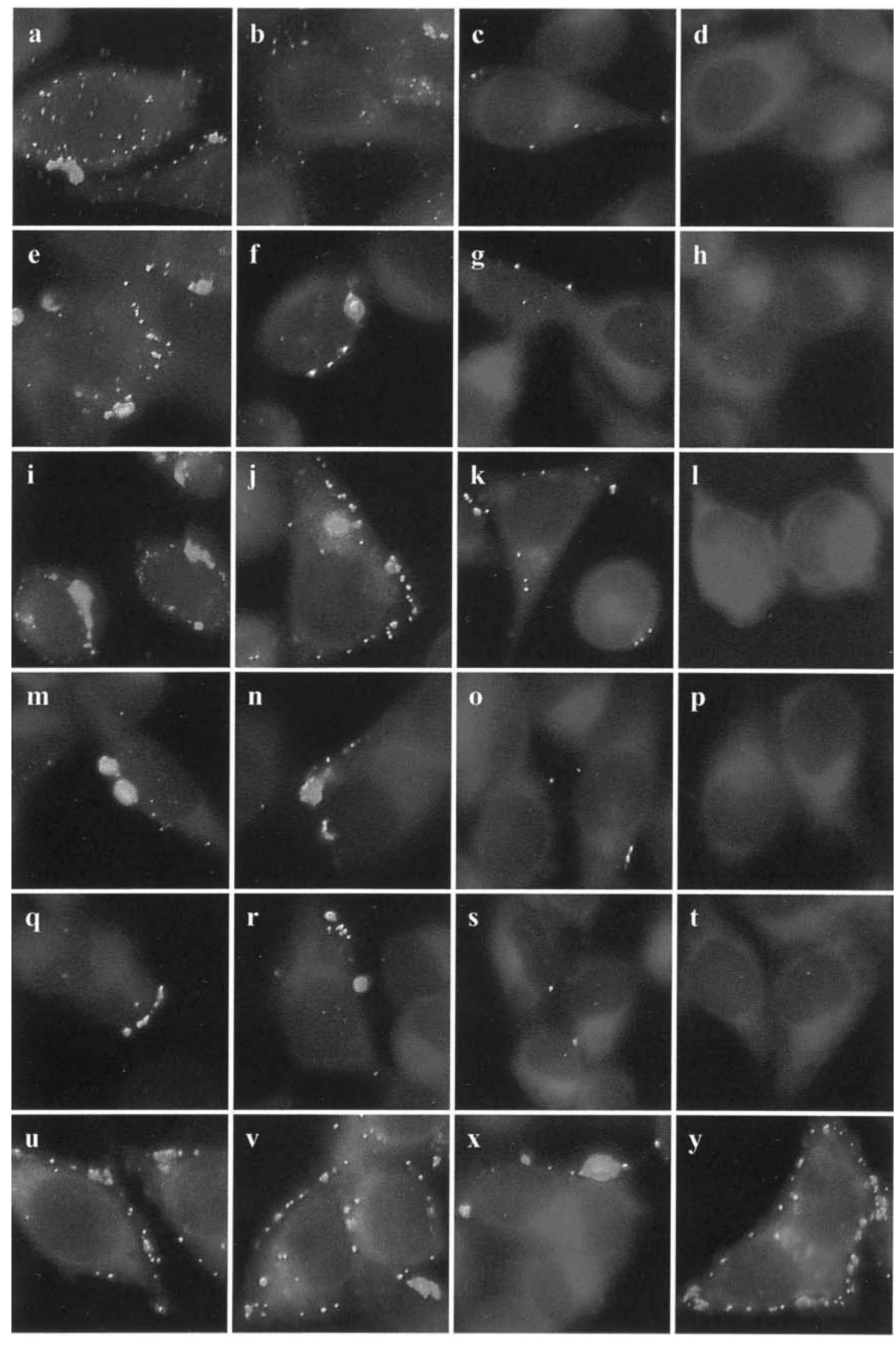

Fig. 4. IFM adhesion inhibition assay. M. genitalium and $M$. pneumoniae were pre-incubated with either polyspecific or monospecific antibodies in different dilutions ( 1 in 50, 1 in 100, 1 in 200, 1 in 400) before infection of the HEp-2 cells. These antibodies were: (a-d) Pab(G37), (e-h) Pab(FH), (i-l) Pab(rMgPa-III), (m-p) Pab(rP1-II), (q-t) Pab(rP116), (u) Pab(rMgPa-I) diluted 1 in 50, (v) Pab(rMgPa-II) diluted 1 in 50, (x) Pab(rP1-I) diluted 1 in 50 and (y) pre-immune serum diluted 1 in 50 . The primary antibodies in the adhesion inhibition assay were $\mathrm{Pab}(\mathrm{G} 37)$ (1 in 2000) and $\mathrm{Pab}(\mathrm{FH})(1$ in 1000$)$ for detection of $M$. genitalium and M. pneumoniae, respectively. Bar, $10 \mu \mathrm{m}$. 
a
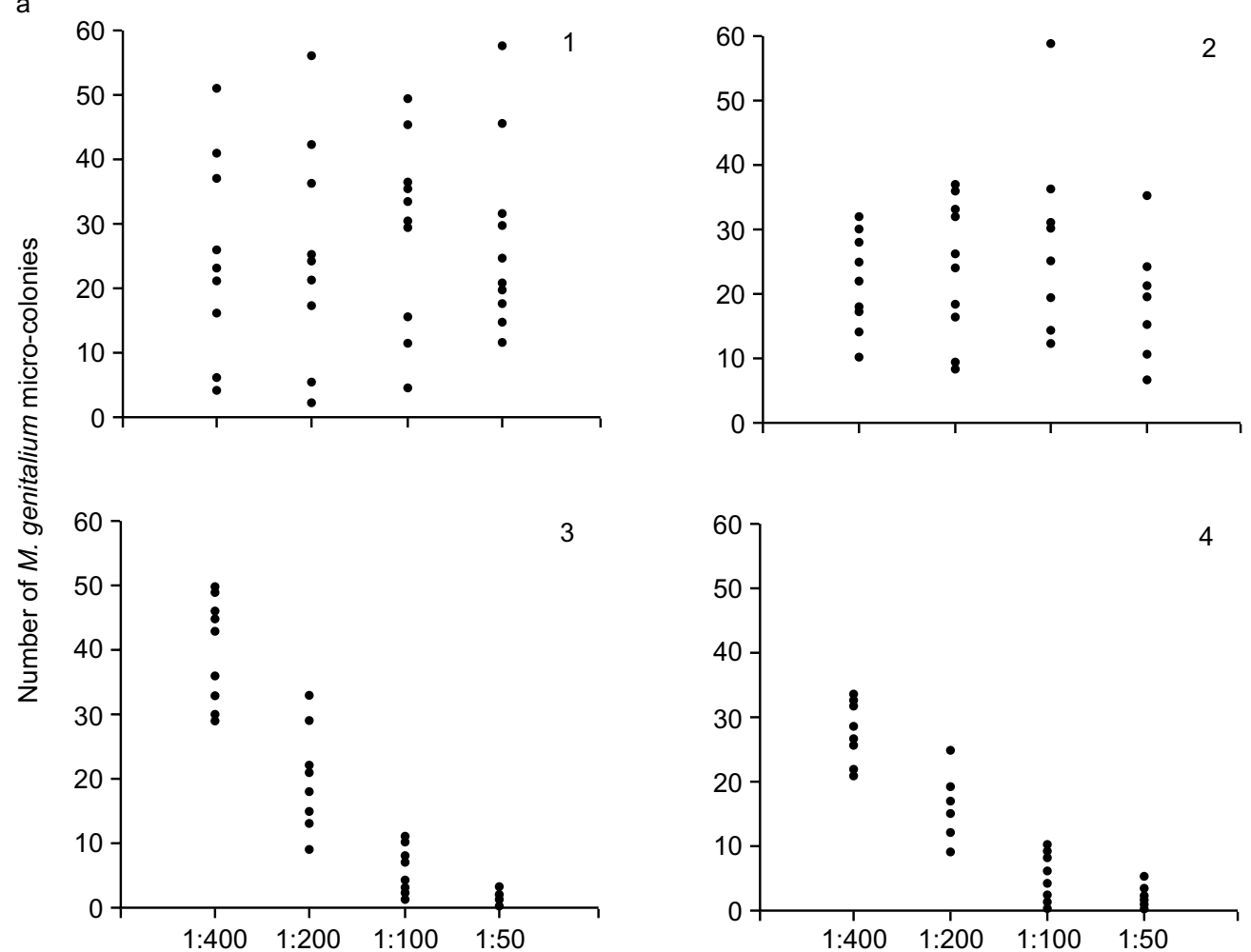

Fig. 5. Results of the IMF adhesion inhibition assay. The number of micro-colonies of cytadhering mycoplasmas is plotted against the dilutions of potential inhibiting antibodies. (a) Plots of the attached M. genitalium micro-colonies for each antibody: $\mathrm{Pab}(\mathrm{rMgPa})$ nos I (1), II (2) and III (3) and Pab(G37) (4). Note that Pab(rMgPa-III) and Pab(G37) reduced the number of colonies when the antibody concentration increased. (b) Adherent micro-colonies of M. pneumoniae with Pab(rP1) nos I (1) and II (2), $\mathrm{Pab}(\mathrm{rP} 116)$ (3), the combination of Pab(rP1-II) and Pab(rP116) (4) and Pab(FH) (5).

cannot be excluded. Nevertheless, it can be concluded that the adherence domain is located near the Cterminal part of both proteins.

Monospecific antibodies against the N-terminal, Pab(rMgPa-I), covering aa 77-320 and the middle part $\mathrm{Pab}(\mathrm{rMgPa}-\mathrm{II})$; aa $830-1009$, of $\mathrm{MgPa}$ did not inhibit M. genitalium from binding to the HEp-2 cells. Neither did the monospecific antibody against the N-terminal part of P1, Pab(rP1-I); aa 185-357, block M. pneumoniae from adhering to the HEp-2 cells. This result was in agreement with the non-surface exposure of the $\mathrm{N}$-terminal and the middle parts of $\mathrm{MgPa}$ and the $\mathrm{N}$ terminal part of P1 as shown by IFM. Furthermore, immunoblotting of N-terminal recombinant proteins (rMgPa-I and rP1-I) was non-reactive with polyspecific antibodies directed against whole mycoplasma cells, $\mathrm{Pab}(\mathrm{G} 37)$ and $\mathrm{Pab}(\mathrm{FH})$. This indicates that the $\mathrm{N}$ terminal part is not exposed on the surface and, therefore, antibodies are not generated to this part during immunisation. The middle part of $\mathrm{MgPa}$ showed a weak reaction in immunoblotting.

The finding of an attachment epitope located in the Cterminal part of P1 of M. pneumoniae (aa 1107-1518) in this study was consistent with the observation by Dallo et al. [38]. They showed a C-terminal region of 13 amino acids involved in cytadhesion (aa 13821394) which is also located in the C-terminal region of
P1 (rP1-II). A C-terminal attachment epitope was also found in the studies of Opitz and Jacobs [39] and Gerstenecker and Jacobs [40] but an adherence region sited only in the C-terminal part was not in agreement with their results. They showed adhesin epitopes to be present in several positions of $\mathrm{MgPa}$ of $M$. genitalium and $\mathrm{P} 1$ of M. pneumoniae.

In the studies of Opitz and Jacobs [39] and Gerstenecker and Jacobs [40], indirect adhesion inhibition assay with inhibiting MAbs against $\mathrm{MgPa}$ of $M$. genitalium and $\mathrm{P} 1$ of $M$. pneumoniae was used. For epitope scanning, the MAbs were used with overlapping octapeptides in ELISA to detect the attachment epitopes. The methods used in these studies are different from those used in the present study and may, therefore, explain the different results.

Interestingly, the adhesion domain found in the Cterminal part of both $\mathrm{MgPa}$ and $\mathrm{P} 1$ has also been determined to be immunodominant in other studies. Recently, we have shown that the most immunogenic region of $\mathrm{MgPa}$ is located in the aa region 1248-1364 [29] in agreement with observations by other groups who have determined the immunodominant regions of P1 to cover aa 1382-1394 [38] and aa 1124-1131 [41], which are both included in rP1-II. Thus, it seems that the adherence and immunogenic epitopes are predominantly located in the C-terminal part of $\mathrm{MgPa}$ and $\mathrm{P} 1$. 

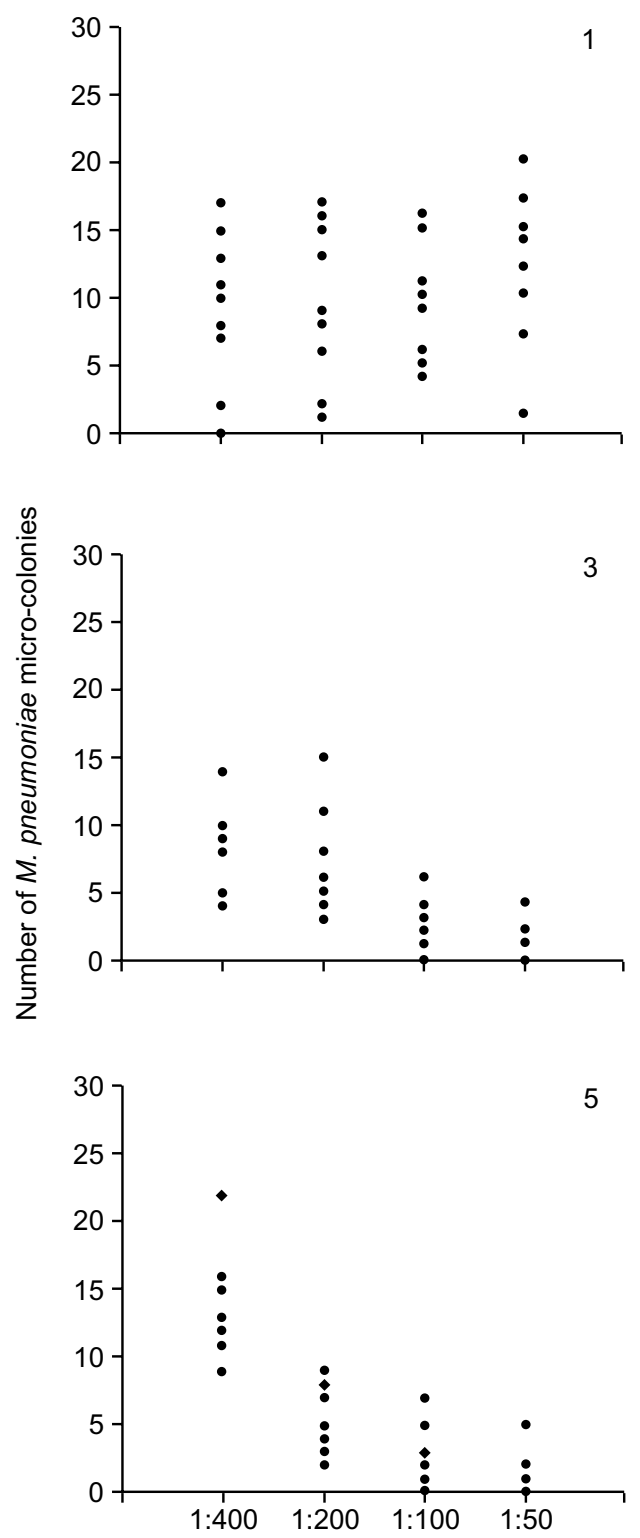

Fig. 5. (continued).

No previous reports have shown whether M. pneumoniae protein $\mathrm{P} 116$ is implicated in adhesion to host epithelial cells. The location of the $116-\mathrm{kDa}$ protein to the surface of $M$. pneumoniae observed by IFM (this study) and by trypsin degradation [22] was in agreement with the immunofluorescence adhesion inhibition results showing that $\mathrm{Pab}(\mathrm{rP} 116)$ was able to block the adherence of $M$. pneumoniae to HEp-2 cells. This implies that the protein P116 of M. pneumoniae is an adhesin implicated in the cytadherence of $M$. pneumoniae, like the two documented adhesins P1 [36] and P30 [27].

Krause and Baseman [37] analysed the adherence of M. pneumoniae proteins to hamster tracheal epithelial cells. They found that radiolabelled $M$. pneumoniae protein of $110 \mathrm{kDa}$, which they denoted P2, was able to bind to the hamster tracheal cells, and the adhesion was competitively inhibited by unlabelled $\mathrm{P} 2$ protein, indi-
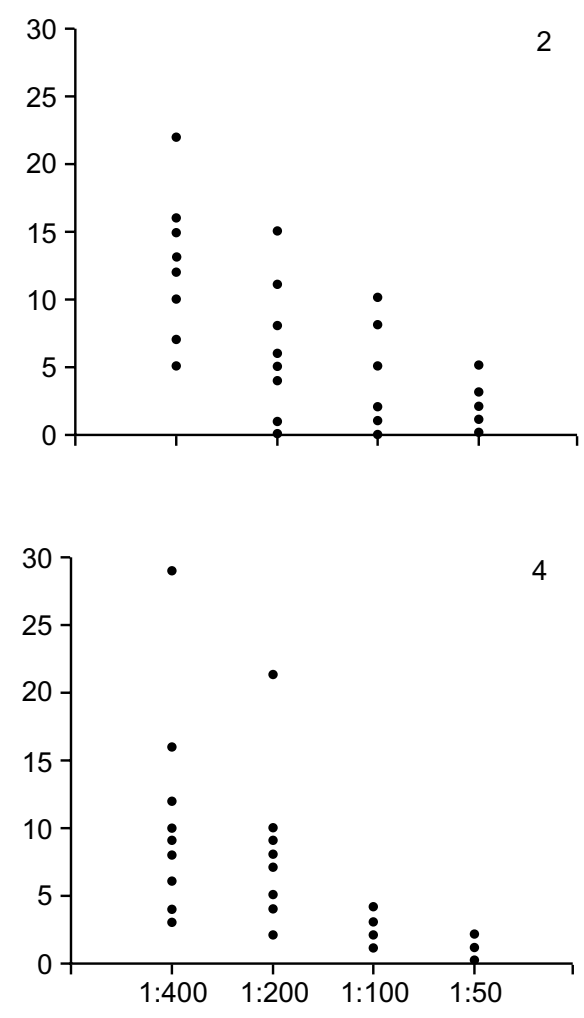

cating a possible role for this protein as an adhesin to a specific host receptor. The P116 (116-kDa protein) of $M$. pneumoniae analysed in this work could be the equivalent of the $\mathrm{P} 2$ protein described by $\mathrm{Hu}$ et al. [36] and Krause and Baseman [37] because the proteins are similar in both size and strong immunogenicity.

Cross-linking studies have shown that the P1 adhesin is complexed to other proteins involved in cytadhesion in the cell membrane of $M$. pneumoniae [23, 24]. However, the $116-\mathrm{kDa}$ protein was not found to be a part of the P1 multi-protein complex at the tip structure of $M$. pneumoniae. The definite location of P116 in the cell membrane in proportion to $\mathrm{P} 1$ or the $\mathrm{P} 1$ multi-protein complex remains to be clarified. Furthermore, it is not known whether P1 and P116 are interdependent in the adherence of $M$. pneumoniae to host epithelial cells. However, the results of the adhesion inhibition assay showed a higher degree of inhibition when both 
Table 3. The number of $M$. genitalium and $M$. pneumoniae micro-colonies per HEp-2 cell in different solutions of Pab.

\begin{tabular}{lcccc}
\hline & \multicolumn{4}{c}{ Number of micro-colonies/HEp-2 cell (percent of positive control) at } \\
antibody dilution
\end{tabular}

The number of micro-colonies was calculated relative to the positive control from the adhesion detection assay (mycoplasma, no Pabs) and given as the percentage (in brackets). Pab(G37) and $\mathrm{Pab}(\mathrm{FH})$ were used as the detecting antibodies for $M$. genitalium and M. pneumoniae, respectively.

$\mathrm{ND}$, not determined.

Pab(rP1-II) and Pab(rP116) were added simultaneously. This may indicate that two ligand sites (P1 and P116) are needed for an efficient adhesion of $M$. pneumoniae to host cells.

The high degree of inhibition activity $(>90 \%)$ of the monospecific antibodies to $\mathrm{MgPa}$ of $M$. genitalium and $\mathrm{P} 1$ and $\mathrm{P} 116$ of M. pneumoniae demonstrated that each of the antigens is crucial for cytadhesion. The attachment of the remaining mycoplasmas could be mediated by accessory adhesion proteins such as P30 of $M$. pneumoniae and the homologous P32 of $M$. genitalium. However, it was expected that the antibodies raised against whole cells of $M$. genitalium and M. pneumoniae would completely inhibit the cytadherence of the mycoplasmas to the HEp-2 cells, but a few mycoplasmas were still attached to the HEp-2 cells at the 1 in 50 antibody dilution. This observation could be due to (i) non-saturating antibody conditions, (ii) the mycoplasmas managing to attach to the HEp-2 cells despite the surface covering antibodies and (iii) avoidance of antibodies because of intra-species variation.

The fact that the antibodies, produced against immunogenic surface proteins in this in-vitro study, reduced the number of attached mycoplasmas suggests a protective function of the humoral immune defence system in vivo. Perhaps the specific antibodies produced by the host give protection against a reinfection with $M$. genitalium or $M$. pneumoniae as suggested in many studies with animal models [4245]. This could explain the greater prevalence of $M$. pneumoniae pneumonia in children and young adults rather than adults and elderly people $[46,47]$ and is in agreement with the proportional correlation between increasing age and the presence of antibodies to $M$. pneumoniae [48].

We thank Karin Skovgaard and Inger Andersen for excellent technical assistance and Lisbet Wellejus Pedersen for linguistic help The research was supported by the Danish Medical Research Council (grant nos 9900750 and 9700659).

\section{References}

1. International committee on systematic bacteriology. Subcommittee on the taxonomy of Mollicutes. Revised minimum standards for description of new species of the class Mollicutes (division Tenericutes). Int J Syst Bacteriol 1995; 45: 605-612.

2. Fraser CM, Gocayne JD, White $\mathrm{O}$ et al. The minimal gene complement of Mycoplasma genitalium. Science 1995; 270: 397-403.

3. Robertson JA, Pyle LE, Stemke GW, Finch LR. Human ureaplasmas show diverse genome sizes by pulsed-field electrophoresis. Nucleic Acids Res 1990; 18: 1451-1455.

4. Bove JM. Molecular features of mollicutes. Clin Infect Dis 1993; 17 Suppl 1: S10-S31.

5. Yamao F, Muto A, Kawauchi Y et al. UGA is read as tryptophan in Mycoplasma capricolum. Proc Natl Acad Sci USA 1985; 82: 2306-2309.

6. Bredt W. Motility. In: Barile MF, Razin S (eds) The mycoplasmas, vol 1; cell biology. New York, Academic Press. 1979: $141-155$.

7. Miyata M, Seto S. Cell reproduction cycle of mycoplasma. Biochimie 1999; 81: 873-878.

8. Seto S, Layh-Schmitt G, Kenri T, Miyata M. Visualization of the attachment organelle and cytadherence proteins of Mycoplasma pneumoniae by immunofluorescence microscopy. J Bacteriol 2001; 183: $1621-1630$.

9. Taylor-Robinson D, Horner PJ. The role of Mycoplasma genitalium in non-gonococcal urethritis. Sex Transm Infect 1977; 77: 229-231.

10. Møller BR, Taylor-Robinson D, Furr PM. Serological evidence implicating Mycoplasma genitalium in pelvic inflammatory disease. Lancet 1984; 1: 1102-1103.

11. Meng KE, Pfister RM. Intracellular structures of Mycoplasma pneumoniae revealed after membrane removal. $J$ Bacteriol 1980; 144: 390-399.

12. Kahane I, Tucker S, Leith DK, Morrison-Plummer J, Baseman JB. Detection of the major adhesin P1 in triton shells of 
virulent Mycoplasma pneumoniae. Infect Immun 1985; 50: 944-946.

13. Niggli V, Burger MM. Interaction of the cytoskeleton with the plasma membrane. J Membr Biol 1987; 100: 97-121.

14. Dirksen LB, Krebes KA, Krause DC. Phosphorylation of cytadherence-accessory proteins in Mycoplasma pneumoniae. J Bacteriol 1994; 176: 7499-7505.

15. Krause DC. Mycoplasma pneumoniae cytadherence: unravelling the tie that binds. Mol Microbiol 1996; 20: 247-253.

16. Hu PC, Huang C-H, Collier AM, Clyde WA. Demonstration of antibodies to Mycoplasma pneumoniae attachment protein in human sera and respiratory secretions. Infect Immun 1983; 41: 437-439.

17. Leith DK, Hansen EJ, Wilson RM, Krause DC, Baseman JB. Hemadsorption and virulence are separable properties of Mycoplasma pneumoniae. Infect Immun 1983; 39: 844-850.

18. Vu AC, Foy HM, Cartwright FD, Kenny GE. The principal protein antigens of isolates of Mycoplasma pneumoniae as measured by levels of immunoglobulin $\mathrm{G}$ in human serum are stable in strains collected over a 10 -year period. Infect Immun 1987; 55: 1830-1836.

19. Baseman JB, Cole RM, Krause DC, Leith DK. Molecular basis for cytadsorption of Mycoplasma pneumoniae. J Bacteriol 1982; 151: 1514-1522.

20. Baseman JB, Morrison-Plummer J, Drouillard D, PuleoScheppke B, Tryon VV, Holt SC. Identification of a 32kilodalton protein of Mycoplasma pneumoniae associated with hemadsorption. Isr J Med Sci 1987; 23: 474-479.

21. Collier AM. Attachment by mycoplasmas and its role in disease. Rev Infect Dis 1983; 5 Suppl 4: S685-S691.

22. Duffy MF, Walker ID, Browning GF. The immunoreactive $116 \mathrm{kDa}$ surface protein of Mycoplasma pneumoniae is encoded in an operon. Microbiology 1997; 143: 3391-3402.

23. Layh-Schmitt G, Herrmann R. Spatial arrangement of gene products of the P1 operon in the membrane of Mycoplasma pneumoniae. Infect Immun 1994; 62: 974-979.

24. Layh-Schmitt G, Podtelejnikov A, Mann M. Proteins complexed to the P1 adhesin of Mycoplasma pneumoniae. Microbiology 2000; 146: 741-747.

25. Tully JG, Taylor-Robinson D, Cole RM, Rose DL. A newly discovered mycoplasma in the human urogenital tract. Lancet 1981; 1: 1288-1291.

26. Inamine JM, Loechel S, Collier AM, Barile MF, Hu PC. Nucleotide sequence of the MgPa (mgp) operon of Mycoplasma genitalium and comparison to the P1 (mpp) operon of Mycoplasma pneumoniae. Gene 1989; 82: 259-267.

27. Hu PC, Schaper U, Collier AM et al. A Mycoplasma genitalium protein resembling the Mycoplasma pneumoniae attachment protein. Infect Immun 1987; 55: 1126-1131.

28. Wang RY, Grandinetti T, Shih JW et al. Mycoplasma genitalium infection and host antibody immune response in patients infected by HIV, patients attending STD clinics and in healthy blood donors. FEMS Immunol Med Microbiol 1997; 19: $237-245$.

29. Clausen HF, Fedder J, Drasbek M et al. Serological investigation of Mycoplasma genitalium in infertile women. Hum Reprod 2001; 16: 1866-1874.

30. Reddy SP, Rasmussen WG, Baseman JB. Molecular cloning and characterization of an adherence-related operon of Mycoplasma genitalium. J Bacteriol 1995; 177: 5943-5951.

31. Wasinger VC, Pollack JD, Humphery-Smith I. The proteome of Mycoplasma genitalium. Chaps-soluble component. Eur J Biochem 2000; 267: 1571-1582.

32. Dhandayuthapani S, Rasmussen WG, Baseman JB. Disruption of gene mg218 of Mycoplasma genitalium through homologous recombination leads to an adherence-deficient phenotype. Proc Natl Acad Sci USA 1999; 96: 5227-5232.

33. Tully JG, Rose DL, Whitcomb RF, Wenzel RP. Enhanced isolation of Mycoplasma pneumoniae from throat washings with a newly modified culture medium. J Infect Dis 1979; 139: $478-482$.

34. Sambrook J, Fritsch EF, Maniatis T. In: Molecular cloning. A laboratory manual, 2nd edn. Cold Spring Harbor, NY, Cold Spring Habor Laboratory Press. 1989.

35. Birkelund B, Andersen H. Comparative studies of mycoplasma antigens and corresponding antibodies. In: Bjerrum OJ, Heegaard NHH (eds) Handbook of immunoblotting of proteins. Technical descriptions. Florida, CRC Press. 1988: 25-33.

36. $\mathrm{Hu}$ PC, Collier AM, Baseman JB. Surface parasitism by Mycoplasma pneumoniae of respiratory epithelium. $J$ Exp Med 1977; 145: 1328-1343.

37. Krause DC, Baseman JB. Inhibition of Mycoplasma pneumoniae hemadsorption and adherence to respiratory epithelium by antibodies to a membrane protein. Infect Immun 1983; 39: $1180-1186$.

38. Dallo SF, Su CJ, Horton JR, Baseman JB. Identification of P1 gene domain containing epitope(s) mediating Mycoplasma pneumoniae cytoadherence. J Exp Med 1988; 167: 718-723.

39. Opitz O, Jacobs E. Adherence epitopes of Mycoplasma genitalium adhesin. J Gen Microbiol 1992; 138: 1785-1790.

40. Gerstenecker B, Jacobs E. Topological mapping of the P1adhesin of Mycoplasma pneumoniae with adherence-inhibiting monoclonal antibodies. J Gen Microbiol 1990; 136: 471-476.

41. Jacobs E, Pilatschek A, Gerstenecker B, Oberle K, Bredt W. Immunodominant epitopes of the adhesin of Mycoplasma pneumoniae. J Clin Microbiol 1990; 28: 1194-1197.

42. Loos M, Brunner H. Complement components (C1, C2, C3, C4) in bronchial secretions after intranasal infection of guinea pigs with Mycoplasma pneumoniae: dissociation of unspecific and specific defense mechanisms. Infect Immun 1979; 25 583-585.

43. Barile MF, Grabowski MW, Kapatais-Zoumbois K, Brown B, $\mathrm{Hu}$ P-C, Chandler DKF. Protection of immunized and previously infected chimpanzees challenged with Mycoplasma pneumoniae. Vaccine 1994; 12: 707-714.

44. Franzoso G, Hu P-C, Meloni GA, Barile MF. Immunoblot analyses of chimpanzee sera after infection and after immunization and challenge with Mycoplasma pneumoniae. Infect Immun 1994; 62: 1008-1014.

45. Cimolai N, Cheong ACH, Morrison BJ, Taylor GP. Mycoplasma pneumoniae reinfection and vaccination: protective oral vaccination and harmful immunoreactivity after re-infection and parenteral immunization. Vaccine 1996; 14: 1479-1483.

46. Cassell GH, Cole BC. Mycoplasmas as agents of human disease. $N$ Engl J Med 1981; 304: 80-89.

47. Clyde WA. Mycoplasma pneumoniae respiratory disease symposium: summation and significance. Yale $\mathrm{J}$ Biol Med 1983; 56: 523-527.

48. Jacobs E, Bennewitz A, Bredt W. Reaction pattern of human anti-Mycoplasma pneumoniae antibodies in enzyme-linked immunosorbent assays and immunoblotting. J Clin Microbiol 1986; 23: $517-522$. 